\title{
Variable prey density modifies the effects of seagrass habitat structure on predator-prey interactions
}

\author{
Rachel Lannin, Kevin Hovel* \\ Department of Biology and Coastal \& Marine Institute, San Diego State University, 5500 Campanile Drive, San Diego, \\ California 92182, USA
}

\begin{abstract}
In seagrass habitats, high structural complexity often enhances prey survival by reducing predator-prey encounter rates and predator foraging success. However, faunal density and biomass typically increase with seagrass structural complexity, such that variation in prey or predator density may contribute to or alter relationships between structural complexity and prey survival. We determined whether variability in prey density alters relationships between seagrass structural complexity and (1) prey survival, (2) predator-prey encounter rates, and (3) behavioral components of predator-prey interactions in eelgrass Zostera marina habitat. Using transplanted eelgrass in laboratory mesocosms, we compared trends in mesopredator (juvenile giant kelpfish Heterostichus rostratus) feeding success and behavior, and predator avoidance behavior by prey (grass shrimp Hippolyte californiensis) between experiments in which we (1) held prey density constant while increasing eelgrass shoot density, or (2) increased prey density while increasing eelgrass shoot density. We found that increasing prey density (but not eelgrass density) enhanced proportional prey survival and decreased the probability that mesopredators would attack prey, whereas increasing eelgrass density (but not prey density) decreased the likelihood that prey would attempt to escape from mesopredator attack. Predator-prey encounter rates were influenced both by prey density and eelgrass density, whereas mesopredator attack success was not influenced by either eelgrass density or prey density. Our results suggest that variable prey density modifies relationships between habitat structure and prey survival through a variety of behavioral mechanisms, and that factors that covary with habitat structure, such as prey density, may alter the effects of habitat structure on predation.
\end{abstract}

KEY WORDS: Epifauna - Habitat structure - Predation - Seagrass - Structural complexity · Zostera marina

\section{INTRODUCTION}

Habitat structure, the physical arrangement of objects in space, strongly influences organismal abundance and diversity in terrestrial, freshwater, and marine ecosystems (Willson 1974, Gorman \& Karr 1978, Heck \& Crowder 1991, McCoy \& Bell 1991, Petren \& Case 1998, Beck 2000). A primary way in which habitat structure influences communities is through its influence on predator-prey relationships. A paradigm regarding the ecology of structured habitats is that predators are inhibited from finding and capturing prey by biotic or abiotic elements of habitat structure (e.g. Crowder \& Cooper 1982, Stoner 1982, Orth et al. 1984, Gotceitas \& Colgan 1990, Heck \& Crowder 1991), which results in decreasing rates of predation (and increasing rates of prey survival) with increasing structural complexity or habitat heterogeneity (van Dolah 1978, Coen et al. 1981, Summerson \& Peterson 1984, Savino \& Stein 1989, Graham et al. 1998, Kunkel \& Pletscher 2000, Anderson 2001, Orth \& van Montfrans 2002, Tarr \& 
Babbitt 2002, Davis et al. 2003). A variety of factors mediate this relationship, however, leading to variability in habitat-survival functions among studies, species, and habitats. At small scales (i.e. within patches), the size of predator and prey organisms relative to the size and spacing of structural elements may influence prey visibility and the ability of predators to maneuver through the habitat (Crowder \& Cooper 1982, Bartholomew et al. 2000, Manatunge et al. 2000). Behavioral responses of prey and predators to structure, including predator foraging modes (Ryer 1988, Michel \& Adams 2009) and prey microhabitat selection, activity levels, and decisions to hide or flee from predators (Stein and Magnuson 1976, Cook \& Streams 1984, Main 1987), may also change with habitat structure and may influence predator-prey encounter rates. Encounter rates may also be influenced by habitat selection by predators, which may select highly complex patches in response to elevated prey density or in response to threats from higher-order predators (Gotceitas \& Colgan 1990), or may select habitat patches of reduced complexity to trade off predation risk for foraging success (Crowder \& Cooper 1982, Werner et al. 1983, Mullin \& Gutzke 1999). Finally, aspects of habitat structure at landscape scales, including proximity to the patch edge (Gates \& Gysel 1978, Paton 1994, Bologna \& Heck 1999, Selgrath et al. 2007), patch size (Andren 1994, Robinson et al. 1995, Irlandi 1997), and landscape context (Donovan et al. 1997), may exert strong influence on the ability of predators to find and capture their prey, and may alter relationships between structural complexity and prey survival (Hovel \& Fonseca 2005).

Seagrasses form complex above and below ground structures in shallow marine systems around the world, and thereby serve as important foraging and refuge habitats for a great number of vertebrate and invertebrate organisms (Williams \& Heck 2001). Due to their refuge value, diverse epifaunal and infaunal communities, and concerns about widespread and accelerating loss and degradation of seagrass habitat (Orth et al. 2006), they have also been widely used as important experimental model systems to determine how habitat structure at multiple spatial scales influences prey survival and predator foraging success (see reviews by Orth et al. 1984, Heck \& Crowder 1991, Orth 1992). In seagrass habitats, survival of epifaunal prey such as small crustaceans (e.g. amphipods, isopods, grass shrimp, and newly settled blue crabs) is often optimal at high levels of structural complexity (commonly measured as shoot density, shoot height, or biomass per unit area) (Heck \&
Thoman 1981, Heck \& Crowder 1991, Hovel \& Lipcius 2001). However, epifaunal density (Stoner 1980, Heck et al. 1989, Orth 1992, Beck 2000) and diversity (Heck \& Wetstone 1977, Attrill et al. 2000, Moore \& Hovel 2010) also typically increase with seagrass structural complexity. Therefore variability in prey survival with seagrass structure may be due both to effects of structure on predator foraging success, and to variation in prey or predator density and community composition with structure. For instance, prey survival did not increase with seagrass structural complexity when prey and predator densities were experimentally increased with structural complexity (Mattila et al. 2008; see also Canion \& Heck 2009), which contrasts the results of numerous studies using constant densities of prey and predators across gradients of habitat structure. Variability in organismal densities with habitat structure therefore should be considered when designing experiments to test for effects of habitat structure on survival (Mattila et al. 2008).

Our goal in this study was to determine whether variability in prey density alters relationships between seagrass structural complexity and (1) prey survival, (2) predator-prey encounter rates, and (3) behavioral components of predator-prey interactions in eelgrass Zostera marina habitat. To accomplish this we conducted mesocosm-based predation experiments using 2 canopy-dwelling species that are abundant in the eelgrass beds of southern California, the mesopredatory juvenile giant kelpfish Heterostichus rostratus and one of its common prey species, the epifaunal grass shrimp Hippolyte californiensis.

\section{MATERIALS AND METHODS}

\section{Study species}

We chose juvenile Heterostichus rostratus (hereafter 'kelpfish') and Hippolyte californiensis (hereafter 'grass shrimp') for our study species due to their high abundance (reaching densities of ca. 2 and 2000 ind. $\mathrm{m}^{-2}$ in southern California eelgrass habitat, respectively; Moore \& Hovel 2010) and their strong trophic linkage. Though the most abundant epifaunal prey item found in the guts of juvenile giant kelpfish are amphipods, grass shrimp are a common component of the diet, composing up to $20 \%$ of the biomass in kelpfish guts (Moore \& Hovel 2010). These 2 species also represent groups of vertebrate mesopredators and invertebrate grazers that may 
exert strong top-down control on seagrass growth and abundance via their predator-prey interaction (Valentine \& Duffy 2006). Kelpfish are active predators that swim slowly within the eelgrass canopy searching for epifaunal prey such as grass shrimp, which are often found clinging to eelgrass blades where they consume epiphytic algae (K. Hovel pers. obs.).

We collected kelpfish (80 to $120 \mathrm{~mm}$ fork length [FL]) with a beach seine and grass shrimp by dip netting within shallow subtidal seagrass habitat in San Diego Bay, California. Collections were performed frequently throughout the experimental period to prevent holding organisms for $>10 \mathrm{~d}$ and to avoid reusing animals in the experiments. Kelpfish and grass shrimp were held in a recirculating seawater system at the Coastal and Marine Institute Laboratory, San Diego State University, before use in experiments. Kelpfish were fed grass shrimp ad libitum for $6 \mathrm{~d}$ while in captivity and were starved for $2 \mathrm{~d}$ before being used in trials. Water temperature was held constant at $20^{\circ} \mathrm{C}$ throughout the experiments.

\section{Experimental design and procedure}

We conducted experiments within glass mesocosms $(122 \times 61 \times 61 \mathrm{~cm})$ filled to a depth of $8 \mathrm{~cm}$ with clean beach sand and then with recirculating seawater to a depth of $45 \mathrm{~cm}$. We varied structural complexity within mesocosms by transplanting eelgrass from San Diego Bay to create 6 shoot densities, each randomly assigned to 1 mesocosm: 20, 40, 80, 160, 250 , or 320 shoots $\mathrm{m}^{-2}$. These values are relatively low for many eelgrass habitats worldwide; however it was necessary to cap our range of shoot densities at $320 \mathrm{~m}^{-2}$ because it was very difficult to observe grass shrimp at higher shoot densities in preliminary trials. Our results and conclusions thus apply only to relatively low levels of eelgrass habitat structure. To examine the relative effects of varying prey density and varying structural complexity on prey survival, encounter rates, foraging behavior of predators, and predator avoidance behavior by prey, we conducted 2 experiments, one in which grass shrimp density was held constant across the 6 levels of structural complexity, and one in which grass shrimp density increased with structural complexity. We used a density of 20 shrimp per mesocosm in the constant prey density experiment, and in the variable prey density experiment we increased shrimp density proportionally with shoot density to maintain an approximate ratio of 1 grass shrimp for every 2 to 3 shoots (Table 1). Our prey densities are comparable to those occurring at our collection site (Moore \& Hovel 2010) and using these prey density levels allowed us to recover $100 \%$ of grass shrimp at the conclusion of trials with minimum disturbance to transplanted eelgrass.

Before transplantation, intact eelgrass shoots were rinsed to remove sediment, macroalgae, and large organisms, and then were soaked in freshwater for $30 \mathrm{~min}$ to remove remaining epifauna from the blades. Shoots were added to mesocosms by tying rhizomes to randomly selected points on a plastic grid buried beneath the sediment. Blades then were trimmed to be flush with the water's surface. Shoots began to decay after $\sim 2 \mathrm{wk}$, at which point mesocosms were randomly assigned a new shoot density treatment and all shoots within each mesocosm were replaced with fresh ones from San Diego Bay. To minimize disturbance by observers during predation trials, we covered 3 sides with opaque white plastic sheeting, and placed a mesh blind over the remaining side. Mesocosms were illuminated by 2 fluorescent Coralife ${ }^{\circledR}$ aquarium bulbs during trials.

Prior to the start of a trial, the experimental tanks were cleaned of any seagrass detritus and detached seagrass blades, and shoots, if necessary, were haphazardly replaced. Grass shrimp (12 to $20 \mathrm{~mm}$ total length) then were added to the tank and were allowed to acclimate for $30 \mathrm{~min}$, after which time the FL of 1 kelpfish was measured and the kelpfish was placed in a plastic mesh container floating within the mesocosm. After 15 min of acclimation, the kelpfish was released by gently inverting the basket and at this point the trial began. For each 75 min trial, 1 observer recorded kelpfish behaviors and 1 observer recorded grass shrimp behaviors using voice re-

Table 1. Structural complexity (number of seagrass shoots) and prey densities (number of grass shrimp) used in the experiments with constant or variable prey density. Numbers in square brackets represent number of shoots or grass shrimp per mesocosm

\begin{tabular}{|c|c|c|}
\hline \multirow[t]{2}{*}{$\begin{array}{l}\text { Structural complexity } \\
(\text { no. shoots m-2) } \\
{\left[\operatorname{mesocosm}^{-1}\right]}\end{array}$} & \multicolumn{2}{|c|}{$\begin{array}{c}\text { Prey density } \\
\text { (no. grass shrimp } \mathrm{m}^{-2} \text { ) } \\
{\left[\mathrm{mesocosm}^{-1}\right]}\end{array}$} \\
\hline & Constant & Variable \\
\hline 20 [14] & 28 [20] & 7 [5] \\
\hline 40 [29] & 28 [20] & 14 [10] \\
\hline $80[67]$ & 28 [20] & 28 [20] \\
\hline $160[114]$ & 28 [20] & $56[40]$ \\
\hline 250 [129] & 28 [20] & 87 [63] \\
\hline $320[220]$ & $28[20]$ & 111 [80] \\
\hline
\end{tabular}


corders (see 'Predator and prey behaviors' below). After $75 \mathrm{~min}$, we removed the kelpfish from the mesocosm and collected all surviving shrimp by dipnetting for $15 \mathrm{~min}$, which was found to be $100 \%$ effective at recovering grass shrimp in pilot experiments using up to 80 grass shrimp without the presence of kelpfish. At the conclusion of each trial, the kelpfish was placed in a plastic container without seagrass in which it was offered an additional 5 'post-trial' grass shrimp for $10 \mathrm{~min}$, after which time we counted the number of post-trial grass shrimp remaining. This was done to determine whether grass shrimp survival rates and kelpfish behaviors could be influenced by satiation as well as structural complexity and prey density, particularly at low levels of structural complexity or high levels of prey density (see 'Statistical analysis' below). We conducted 4 replicates for each structural complexity treatment with constant shrimp density $(\mathrm{n}=24)$, and 6 replicates for each shoot density with variable shrimp density $(\mathrm{n}=36)$ between March and October 2009.

\section{Predator and prey behaviors}

We quantified several distinct components of predator-prey interactions that affect predator foraging efficiency and that may be influenced by structural complexity or prey density (Ryer 1988; see Table 2). (1) We identified a predator-prey encounter as an obvious fixation of both eyes of the kelpfish on a grass shrimp, accompanied by a halt in swimming (sensu Ryer 1988). Thus, an encounter involves an obvious detection of prey by kelpfish, but would not include a 'passive' detection made without an obvious change in kelpfish behavior, which we would not be able to identify. In addition to counting the number of encounters per trial, we divided the number of encounters by the starting number of prey to serve as a measure of the probability that an individual grass shrimp would encounter a kelpfish. (2) After detecting prey, predators must choose whether to attack, and attacks may or may not be successful. We therefore calculated the proportion of encounters that resulted in attacks by kelpfish and the proportion of attacks that were successful. Though we also counted the number of unsuccessful attacks that were followed by a pursuit of prey by kelpfish, there were too few pursuits to conduct statistical analysis. (3) We quantified the total number of seconds kelpfish spent in motion, and calculated proportional kelpfish activity by dividing the number of seconds spent in motion by the total number of seconds in a trial (4500). High rates of activity suggest predators are engaging in active hunting, whereas low rates of activity suggest a sitand-pursue strategy (Savino \& Stein 1989, Michel \& Adams 2009). (4) Predator foraging efficiency also may depend on the tendency of prey to detect predators and attempt to flee from them, and we therefore calculated the proportion of encounters that resulted in escape attempts by grass shrimp prey (before an attack or after an unsuccessful attack), and the number of times shrimp switched sides of seagrass blades ('side switching'). Side switching was used by the grass shrimp Tozeuma carolinense to avoid being detected or pursued by predators (Main 1987) and we observed Hippolyte californiensis performing this behavior in pilot experiments. To record side switching, we haphazardly selected individual shrimp to observe for $5 \mathrm{~min}$ intervals, during which we recorded the number of switches. The total number of switches observed during a trial was divided by the number of shrimp observed (11 per trial on average) to yield an average frequency per $5 \mathrm{~min}$ interval.

\section{Statistical analysis}

For the analysis of grass shrimp proportional survival, we first determined whether possible satiation of the kelpfish at low levels of structural complexity or at high levels of prey density was influencing apparent effects of structural complexity and prey density on prey survival rates. We used linear regressions to determine whether the number of post-trial grass shrimp consumed by kelpfish varied with seagrass shoot density in the constant prey density experiment, or with grass shrimp density in the variable prey density experiment. We found no relationship between structural complexity and the number of post-trial grass shrimp consumed by kelpfish in the constant prey density experiment $(\mathrm{df}=1,22, F=2.2$, $\left.\mathrm{p}=0.14, \mathrm{r}^{2}=0.05\right)$. For the variable prey density experiment, kelpfish consumed at least some of the offered post-trial grass shrimp at all prey density levels, but the total number of post-trial grass shrimp consumed decreased with grass shrimp density ( $\mathrm{df}=$ $\left.1,32, F=12.1, \mathrm{p}=0.001, \mathrm{r}^{2}=0.25\right)$. To ensure that this did not result in artificially inflated rates of survival at high levels of grass shrimp density, we calculated an adjusted grass shrimp proportional survival for our 2 highest density treatments by dividing the number of surviving grass shrimp by the maximum number of 
shrimp (49) a fish was observed to eat over $75 \mathrm{~min}$ in pilot experiments. All other shrimp densities were below the maximum number that kelpfish were observed to eat, so for those densities grass shrimp proportional survival was calculated by dividing the number of surviving grass shrimp by the starting number of shrimp.

We used linear regression, non-linear regression, and a comparison of slopes procedure (Zar 2009) to test whether the influence of structural complexity on grass shrimp proportional survival, as well as all behavioral variables, differed between the 2 grass shrimp experiments (constant versus variable prey density). We originally included fish FL as an independent variable in our analyses, but removed it from final analyses as it did not contribute significantly to statistical models. For each dependent variable (see Table 2), we first ran separate least-squares linear regressions to obtain best-fit lines and residuals for each experiment. If data appeared strongly heteroscedastic across structural complexity treatments and included 1 or more extreme outliers (i.e. standardized residual $\geq 3.0$ ), we used least-trimmed squares robust regression rather than linear regression to generate best-fit lines (Gotelli \& Ellison 2004). If, upon visual inspection, residuals from both regressions were random, we then tested whether effects of structural complexity on the dependent variable differed between the constant and variable shrimp treatments using a $t$-test for equality of slopes (Zar 2009). If the residuals from 1 or both initial regressions appeared non-random, we used quadratic regression to test for a non-linear relationship between the dependent variable and seagrass structural complexity. We assumed the relationship to be non-linear if the quadratic regression was significant and explained a larger proportion of the variance in the dependent variable than did the linear regression (Zar 2009).

Several outcomes were possible for each dependent variable examined in our experiments. (1) Significant relationships between structural complexity and the dependent variable may be similar (i.e. have equal slopes) between the 2 experiments. This would suggest that structural complexity, but not prey density, influences the dependent variable. (2) Significant relationships between the dependent variable and structural complexity may be dissimilar between the 2 experiments, which would suggest that structural complexity influences the dependent variable, but variable prey density modifies this relationship. (3) A significant relationship between the dependent variable and structural complexity may exist only for one of the experiments. For instance, if a relationship between the dependent variable and structural complexity exists only when prey density increases with structural complexity, this would suggest that (1) only prey density influences the dependent variable, or (2) the effects of structural complexity and prey density are additive. We were not able to distinguish between these 2 possibilities because we did not vary prey density while standardizing structural complexity. We did not include such an experiment because we were interested in whether variability in prey density would alter the relationship between structural complexity and each dependent variable. (4) Lack of a significant relationship between the dependent variable and structural complexity in both experiments would suggest that neither structural complexity nor prey density influence the dependent variable.

\section{RESULTS}

\section{Grass shrimp survival}

Relationships between seagrass structural complexity and grass shrimp proportional survival differed between experiments: proportional survival was correlated with structural complexity only when prey density increased with structural complexity (Table 2, Fig. 1). Thus, grass shrimp density rather than structural complexity influenced proportional survival, or the effects of the 2 independent variables on survival were additive. A hyperbolic line provided the best model fit, indicating that proportional grass shrimp survival increased with shrimp density and structural complexity relatively rapidly at low to moderate shrimp densities, but leveled off thereafter (Fig. 1).

\section{Components of predator efficiency}

Both structural complexity and prey density influenced the total number of encounters during a trial, as well as the number of encounters per prey (Table 2, Fig. 2). Encounters per trial decreased linearly with structural complexity when prey density was held constant, but there was a parabolic relationship between encounters and structural complexity when prey density varied. Thus, increasing prey density from low to intermediate levels increased encounter rates despite increases in structural complexity, but encounter rates decreased from interme- 
Table 2. Linear and non-linear regressions and slope comparisons for relationships between seagrass structural complexity and dependent variables used to analyze predator-prey interactions between juvenile giant kelpfish Heterostichus rostratus and grass shrimp Hippolyte californiensis (see 'Materials and methods'). Slope comparisons indicate the significance of differences between results obtained with constant and variable prey densities. na: slope comparison not possible due to nonlinearity for one or both experiments. The final columns indicate, for each dependent variable, whether combined results

suggest an effect of structural complexity (SC) or prey density (PD). p-values $<0.1$ are in bold

\begin{tabular}{|c|c|c|c|c|c|c|c|c|c|c|c|c|c|}
\hline \multirow{3}{*}{$\begin{array}{l}\text { Dependent } \\
\text { variable }\end{array}$} & \multicolumn{8}{|c|}{ — Prey density } & \multirow{2}{*}{\multicolumn{3}{|c|}{$\begin{array}{c}\text { Slope } \\
\text { comparisons }\end{array}$}} & \multirow{2}{*}{\multicolumn{2}{|c|}{$\begin{array}{l}\text { Inter- } \\
\text { pretation }\end{array}$}} \\
\hline & & - Con & stant- & & & -Vari & able & & & & & & \\
\hline & df & $F$ & $\mathrm{p}$ & $r^{2}$ & df & $F$ & $\mathrm{p}$ & $\mathrm{r}^{2}$ & $\mathrm{df}$ & $t$ & $\mathrm{p}$ & $\mathrm{SC}$ & PD \\
\hline Proportional prey survival & 1,22 & 0.61 & 0.44 & 0.0 & 2,30 & 12.3 & $<0.001$ & 0.41 & & na & & No & Yes \\
\hline No. of encounters per trial & 1,18 & 3.86 & 0.06 & 0.13 & 2,31 & 3.17 & 0.05 & 0.12 & & na & & Yes & Yes \\
\hline No. of encounters per prey & 1,22 & 9.75 & 0.005 & 0.28 & 2,31 & 15.4 & $<0.001$ & 0.46 & & na & & Yes & Yes \\
\hline Attack probability & 1,22 & 0.00 & 0.93 & 0.0 & 1,32 & 6.42 & 0.02 & 0.14 & 56 & 2.8 & 0.03 & No & Yes \\
\hline Proportional success of attacks & 1,17 & 0.44 & 0.84 & 0.0 & 1,29 & 0.94 & 0.34 & 0.0 & 46 & 0.0 & 1.0 & No & Yes \\
\hline Proportional predator activity & 1,22 & 2.3 & 0.14 & 0.05 & 1,32 & 0.01 & 0.95 & 0.0 & 54 & 1.94 & 0.06 & No & No \\
\hline Escapes per encounter & 2,21 & 11.1 & $<0.001$ & 0.46 & 2,31 & 3.9 & 0.03 & 0.15 & & na & & Yes & No \\
\hline Prey side switching frequency & 1,15 & 0.99 & 0.34 & 0.0 & 1,24 & 0.36 & 0.56 & 0.0 & 39 & 1.58 & 1.2 & No & No \\
\hline
\end{tabular}

diate to our highest levels of structural complexity despite increases in prey density (Fig. 2A). In contrast, the probability that an individual grass shrimp prey would encounter a kelpfish (i.e. encounters per prey) decreased both for constant shrimp density and variable shrimp density, but the relationship was linear for constant shrimp density and non-linear for variable shrimp density (Table 2, Fig. 2B). We therefore conclude that both structural complexity and prey density influence encounters per prey because varying prey density with structural complexity altered the nature of the relationship. The magnitude of the difference between the 2 experiments was highest at the lowest levels of structural complexity, and therefore low prey density increased the proba-

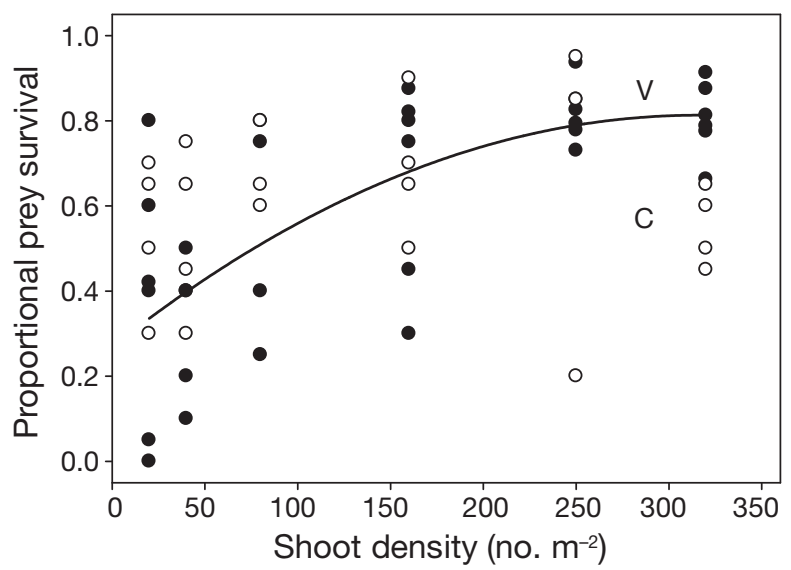

Fig. 1. Hippolyte californiensis. Relationship between seagrass shoot density and grass shrimp proportional survival in the presence of predatory juvenile giant kelpfish in mesocosm experiments in which shrimp density increased as seagrass shoot density increased $(\mathrm{V}, \mathbf{0})$ or remained constant as shoot density increased $(\mathrm{C}, \mathrm{O})$ bility that a grass shrimp would encounter a kelpfish at very low structural complexity.
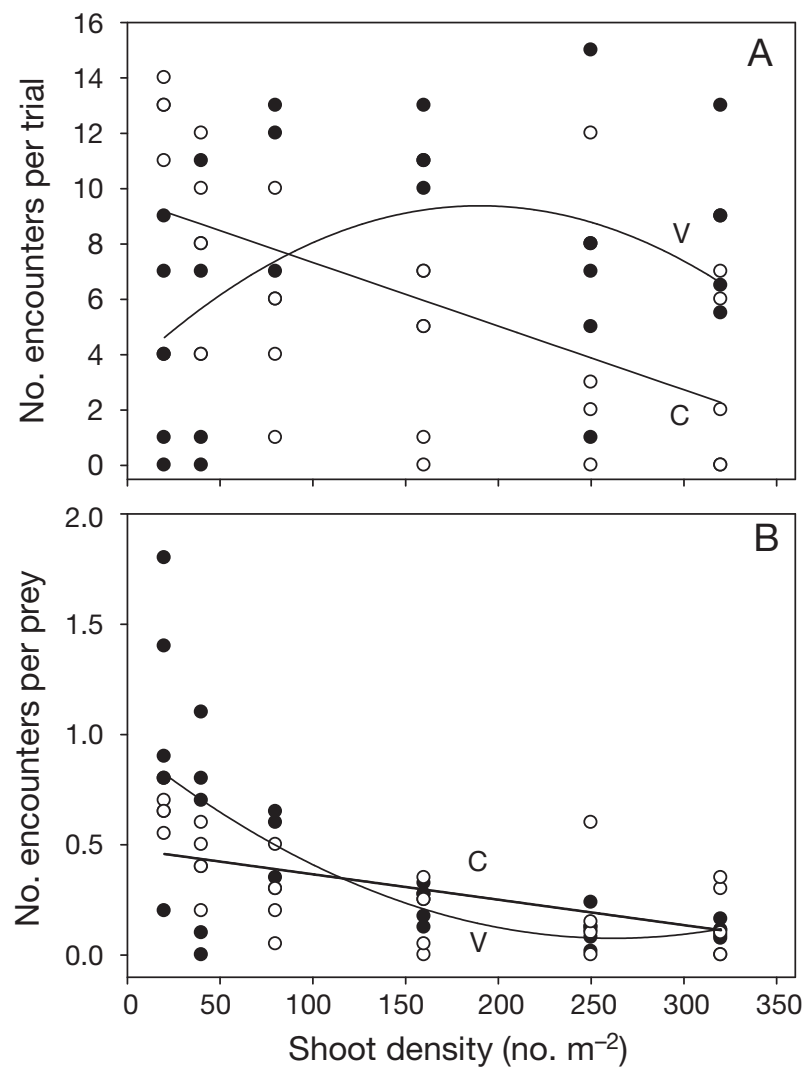

Fig. 2. Hippolyte californiensis and Heterostichus rostratus. Relationship between seagrass shoot density and (A) total number of encounters between grass shrimps and predatory juvenile giant kelpfish, and (B) number of encounters per prey, in mesocosm experiments in which shrimp density increased as seagrass shoot density increased $(\mathrm{V}, 0)$ or remained constant as shoot density increased $(\mathrm{C}, \mathrm{O})$ 

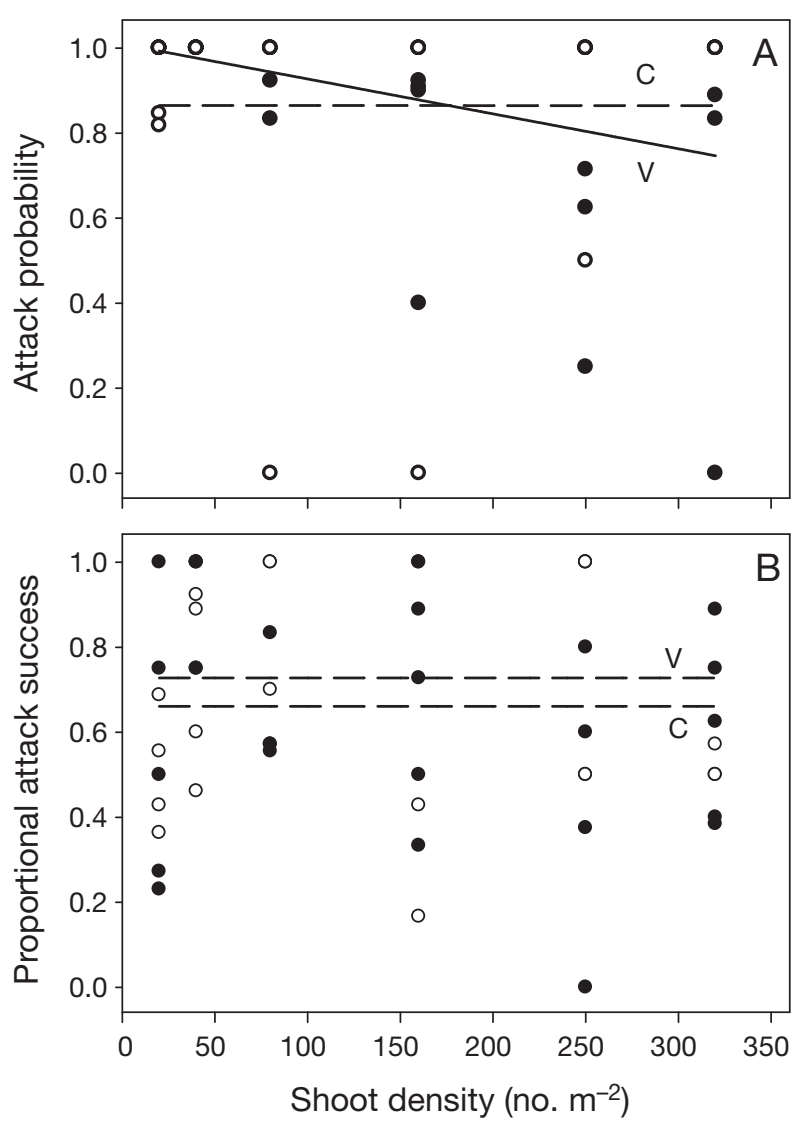

Fig. 3. Heterostichus rostratus. Relationship between seagrass shoot density and (A) total number of attacks on grass shrimps by juvenile giant kelpfish, and (B) proportional predator attack success, in mesocosm experiments in which shrimp density increased as seagrass shoot density increased $(\mathrm{V}, \boldsymbol{\theta})$ or remained constant as shoot density increased $(\mathrm{C}, \mathrm{O})$. Dashed lines represent non-significant regressions and are shown to illustrate results for slopes comparison

Attack probability decreased linearly with structural complexity only when shrimp density increased with structural complexity; therefore prey density, but not structural complexity, influenced the probability that kelpfish would attack prey after detecting them (Table 2, Fig. 3A). Though this could result from additive effects of the 2 independent variables, we conclude that this is unlikely because the slope of the best-fit line for attack probability versus structural complexity was nearly zero. Kelpfish attacked detected prey $100 \%$ of the time at very low prey densities, but on average attacked ca. $75 \%$ of the time at the highest prey density. In contrast, neither structural complexity nor prey density influenced proportional attack success by kelpfish (Table 2, Fig. 3B). On average, kelpfish were successful on $\sim 66 \%$ of attacks when prey density was held con- stant, and successful on $72 \%$ of attacks when prey density varied.

There was little evidence for a correlation between proportional activity and structural complexity for either experiment (Table 2, Fig. 4). However comparison of slopes in Fig. 4 provided relatively strong evidence that the relationship between proportional kelpfish activity and seagrass structural complexity differed between the 2 experiments $(p=0.06)$.

\section{Prey behaviors}

Overall, grass shrimp attempted to escape on $46.8 \%( \pm 4.7 \% \mathrm{SE})$ of encounters with kelpfish, with $\sim 80 \%$ of escapes coming after a kelpfish had initiated an attack. Structural complexity, and not prey density, influenced grass shrimp escape attempts: the proportion of encounters on which shrimp attempted to escape decreased with structural complexity regardless of constant or varying prey density (Table 2, Fig. 5A). Both relationships were non-linear, precluding a comparison of slopes between treatments, but relationships were similar enough to conclude that prey density had little effect on the tendency for prey to attempt escape. We found no evidence that structural complexity or prey density influenced the frequency that grass shrimp switched sides of seagrass blades (Table 2, Fig. 5B).

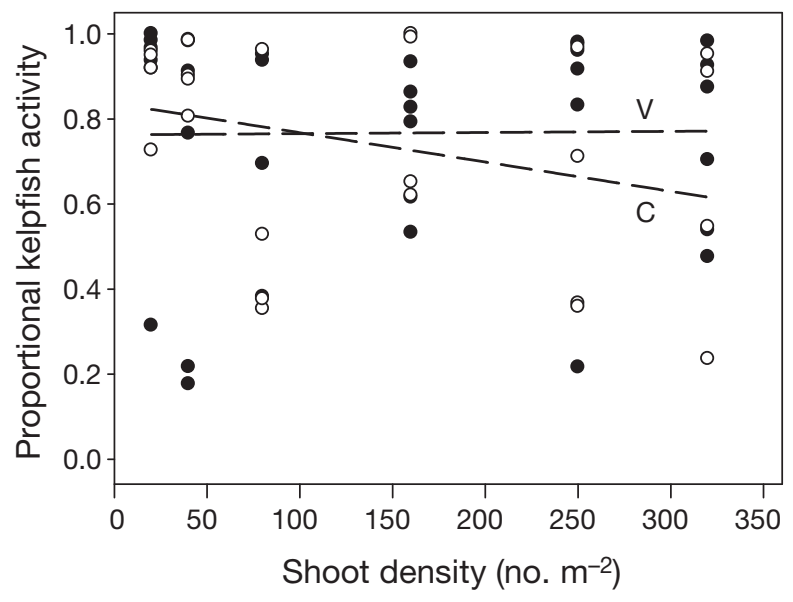

Fig. 4. Heterostichus rostratus. Relationship between seagrass shoot density and the proportion of trial time that juvenile giant kelpfish spent in motion in mesocosm experiments in which shrimp density increased as seagrass shoot density increased $(\mathrm{V}, \mathbf{0})$ or remained constant as shoot density increased $(\mathrm{C}, \mathrm{O})$. Dashed lines represent non-significant regressions and are shown to illustrate results for slopes comparison 

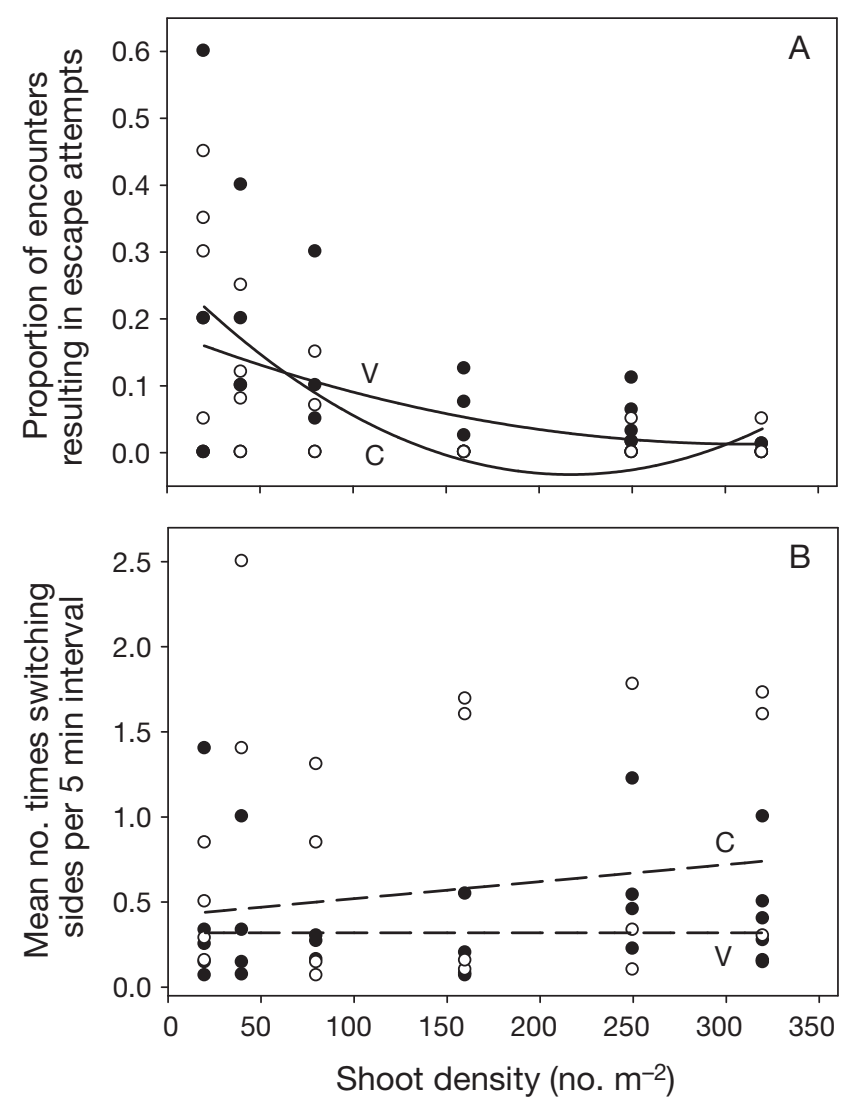

Fig. 5. Hippolyte californiensis. Relationship between seagrass shoot density and (A) the proportion of encounters with juvenile giant kelpfish that resulted in grass shrimp escape attempts, and (B) the mean number of times that grass shrimp switched sides of seagrass blades per $5 \mathrm{~min}$ interval, in mesocosm experiments in which shrimp density increased as seagrass shoot density increased $(\mathrm{V}, \boldsymbol{\bullet})$ or remained constant as shoot density increased $(C, O)$. Dashed lines represent non-significant regressions and are shown to illustrate results for slopes comparison

\section{DISCUSSION}

A primary conclusion from our experiments is that variability in prey density may influence survival and the behavioral mechanisms involved in predatorprey interactions as much as, or more than variability in structural complexity, at least at the relatively low levels of eelgrass structural complexity used in our experiments. Specifically, we found that prey survival only increased with eelgrass structural complexity when prey density also increased with structural complexity, and that prey density modified the effects of structural complexity on several components of predator-prey interactions, including encounter rates and decisions by predators to attack prey. Our results suggest that mechanisms by which habitat structure appears to influence predator-prey interactions should not be taken for granted, and that it is important to consider factors that often covary with habitat structure in nature, such as organismal densities and behaviors, when assessing the outcomes of predator-prey interactions in structurally complex habitats (Savino \& Stein 1982, Ryer 1988, Mattila et al. 2008, Stoner 2009).

\section{Prey survival, prey density, and structural complexity}

Habitat structure and prey density both strongly influence prey survival in terrestrial and marine habitats. Though various studies have addressed how variability in habitat structure influences relationships between prey density and prey survival (e.g. effects of habitat on predator functional response; Lipcius \& Hines 1986, Sponaugle \& Lawton 1990, Moksnes et al. 1997, Seitz et al. 2001) far fewer studies have addressed the converse (i.e. how variable prey density influences effects of habitat structure on prey survival; Mattila et al. 2008). In one of the few studies that tested relative effects of structural complexity and prey density on predator foraging efficiency, Gotceitas \& Colgan (1990) found that rates of predator (bluegill sunfish) consumption of damselfly nymph prey were higher in simulated aquatic vegetated habitat with high levels of prey density, even when high prey density patches had 5 -fold higher stem density than low prey density patches. This suggests that positive effects of prey density on predator consumption rates offset negative effects of structural complexity. Our results were similar in that prey density had a strong influence on prey survival, but in our study system predator consumption rates decreased rather than increased with prey density. In contrast to our study and to Gotceitas \& Colgan (1990), consumption of epibenthic amphipods by the predatory pink shrimp Farfantepenaeus duorarum in Gulf of Mexico seagrass beds decreased with habitat structural complexity, but did not vary with amphipod density (Corona et al. 2000).

The common belief that increasing seagrass structural complexity automatically results in decreased predator efficiency, and increased prey survival, has been questioned in recent studies. Using shrimp (Palaemonetes pugio) as prey and pinfish Lagodon rhomboides as predators, Mattila et al. (2008) and Canion \& Heck (2009) found that prey survival did not increase with simulated seagrass (Thalassia tes- 
tudinum) structural complexity in laboratory experiments in which prey and predator densities both were increased with structural complexity. These results led Mattila et al. (2008) and Canion \& Heck (2009) to suggest that high levels of seagrass structural complexity may not enhance prey survival as commonly as believed, because prey and predator densities often increase with structural complexity in naturally occurring seagrass habitat. We chose to hold predator density constant in our experiments because we wanted to focus on the interactive effects of structural complexity and prey density, which commonly covary in seagrass habitat. Moreover, results of throw-trap sampling in San Diego Bay from June to August 2010 suggest that kelpfish density does not increase with eelgrass shoot density ( $\mathrm{df}=$ $1,28, F=2.1, p=0.16, r^{2}=0.04 ; \mathrm{K}$. Hovel unpubl. data). Nonetheless, our conclusions regarding prey survival may have differed had we increased predator density along with prey density and eelgrass structural complexity. What is important to conclude from our study as well as from Mattila et al. (2008) and Canion \& Heck (2009) is that the effects of seagrass habitat structure on prey survival depend on organismal densities as well as on structural complexity.

\section{Behavioral components of predator-prey interactions}

Though studies documenting relationships between prey survival and habitat structure are common in marine systems, relatively few studies have examined the specific mechanisms by which habitat structure influences predator-prey interactions (but see Ryer 1988, Ryer et al. 2004, Stoner 2009). We are not aware of any study that has examined the relative effects of habitat structure and prey density on these mechanisms in structured marine habitats (but see e.g. Manatunge et al. 2000 for an example of this approach with freshwater macrophytes). There are several components to predator-prey interactions, each of which may be influenced by structural complexity and prey density (Ryer 1988): (1) prey detection by predators, (2) decisions by predators to attack prey, (3) predator success in capturing prey, and (4) decisions by predators to pursue prey in the event they are unsuccessful. In addition, habitat structure and prey density may influence (5) the ability of prey to detect threats from predators and to take action to avoid attacks (Savino \& Stein 1982, Ryer et al. 2004). By examining each of these behav- ioral components, the mechanisms structuring relationships between prey survival (or conversely predator foraging success) and habitat structure can be elucidated.

Our results suggest that seagrass structural complexity and prey density drive patterns of prey survival primarily through variability in rates of prey detection by predators, and that variability in prey density plays an important role in determining the likelihood that an individual prey organism encounters a predator. We found an inverse correlation between seagrass structural complexity and per capita encounter rates regardless of whether prey density increased with seagrass structure or remained constant. However, per capita encounter rates decreased quickly to a lower plateau when prey density increased with structural complexity, but decreased only slightly (though significantly) with structural complexity when prey density was held constant (Fig. 2B). Concomitantly, proportional prey survival increased quickly to an upper plateau as prey density and structural complexity increased, but increased only slightly (and non-significantly) with structural complexity when prey density was held constant. Decisions by predators to attack detected prey also may have played a role in the outcome of our experiments. A moderate decrease in attack probability as prey density increased may have strengthened the relationship between survival and prey density, thereby contributing to differences in survival between our 2 experiments.

Prey behavior also may have influenced patterns of prey survival. The decrease in grass shrimp escape attempts with structural complexity is likely due to reduced ability of grass shrimp to detect approaching and attacking predators. Though there were similar patterns between the 2 experiments, differences among levels of structural complexity in the ability of grass shrimp to detect predators appeared to be somewhat larger when prey density was held constant than when prey density varied. This suggests that the lack of a positive effect of structural complexity on grass shrimp survival may have been partially due to decreased ability of grass shrimp to detect threats as structural complexity increased. Though it is unclear why increasing prey density with structural complexity would slightly modify this effect, one possibility is that grass shrimp observe more escape attempts from conspecifics when prey density is high, and therefore are more vigilant. Regardless of whether prey density increased with structural complexity or remained constant, the overall frequency of prey escape attempts was relatively 
small, suggesting that prey behavior played less of a role than predator behavior in structuring prey survival. We suggest, however, that theories on effects of habitat structure of prey survival should incorporate the concept that increasing habitat structure may work to conceal foraging predators as well as vulnerable prey (Griesser \& Nystrand 2009).

Reduced predator-prey encounter rates in highly complex habitats are commonly caused by interference of structural elements with predator vision. For instance, largemouth bass Microterus salmoides detection of prey (bluegill sunfish Lepomis macrochirus) decreased with increasing density of artificial plant stems, though differences in prey behavior among stem densities also influenced predation success (Savino \& Stein 1982). Pipefish Sygnathus fuscus detection rates of amphipod prey were lower in structurally complex artificial seagrass than in structural simple artificial seagrass (Ryer 1988), and detection of Daphnia pulex by the topmouth gudgeon Pseudorasbora parva decreased with increasing densities of artificial macrophyte stems (Manatunge et al. 2000). In contrast, sponge habitat structure did not decrease detection rates of juvenile rock sole Lepidopsetta polyxstra and age-0 Pacific halibut Hippoglossus stenolepis by predatory age- 2 Pacific halibut in laboratory experiments; rather, sponges served as a barrier to predator movement, thus interfering with predator search and capture (Ryer et al. 2004).

Predator activity levels often decrease with habitat structure as predators switch from active searching to sit-and-pursue predation (Savino \& Stein 1982, Ryer 1988, Michel \& Adams 2009), which may help reduce the negative effects of structural complexity on foraging efficiency. Predatory beetle (Dytiscus spp.) larvae switched from actively foraging to a sitand-pursue foraging strategy as structural complexity increased, resulting in similar rates of prey capture among levels of structural complexity (Michel \& Adams 2009) as was true for lined seahorses Hippocampus erectus feeding on grass shrimp Hippolyte zostericola in simulated seagrass habitat (James \& Heck 1994). We did not find effects of seagrass habitat structure on predator activity levels, though we observed a weak trend for kelpfish to decrease activity levels with increasing structure when prey density was held constant. This trend may have been stronger if we had used higher levels of structural complexity; in fact, in follow-up experiments using simulated seagrass within mesocosms, kelpfish activity was significantly reduced at a higher shoot density $\left(600 \mathrm{~m}^{-2}\right)$ than used herein (K. Hovel unpubl. data).
We also did not observe changes in prey behaviors with habitat structure that minimize encounter rates with predators. We predicted that side switching by grass shrimp, which puts an opaque barrier between predator and prey, would be more frequent at low levels of structural complexity, but this was not observed. In contrast, grass shrimp Tozeuma carolinense exhibited strong reaction to predators by moving around seagrass blades and reducing time spent in motion (i.e. walking on blades: Main 1987). Juvenile Pacific halibut were more likely to remain motionless when approached by a predator within structured habitat than within open sand (Ryer et al. 2004) and juvenile red king crabs associate with structure to a greater degree when predators are present than when they are absent (Stoner 2009). In addition to changes in behavior by individual prey organisms, prey may form groups that reduce per capita mortality rates, particularly at low levels of structural complexity (Anderson 2001). In experimental pools, sunfish schooled for protection from largemouth bass at low artificial stem densities and dispersed among stems at high stem densities (Savino \& Stein 1982). Swarming by mysids (Paramesopodopsis rufa) was effective at reducing per capita mortality in the absence of structural complexity, but the addition of structural complexity to experimental tanks reduced the effectiveness of swarming by disrupting the structure of the swarm (Flynn \& Ritz 1999).

\section{CONCLUSIONS}

Though structural complexity often varies substantially within and among patches and habitats, biotic and abiotic factors that covary with complexity may strongly influence predator-prey interactions. We demonstrated that prey density modifies the effects of seagrass structural complexity on predation, and that different components of predator-prey interactions respond to variability in prey density in different ways. Caveats of our study include the fact that we used relatively low levels of seagrass densities and prey densities in our experiments, as well as only one pair of predator-prey species. Our results should be extrapolated to other, denser seagrass habitats or to other species cautiously; more research is needed for other seagrass habitats and species, and to investigate interactions at higher levels of structural complexity and prey density. We worked in a controlled laboratory setting in which organisms were not able to choose among habitats or levels of 
structural complexity. In naturally occurring seagrass habitat, abiotic factors such as currents (that bend seagrass blades and affect swimming ability), turbidity (that influences detection ranges for predators and prey), water depth, temperature, and proximity to alternative patches and habitats (that allow prey an alternative means of avoiding predators) may interact with structural complexity and prey density to mediate predator-prey interactions. The presence of higher-order predators that represent a threat to mesopredators such as kelpfish also may strongly influence foraging behaviors and survival rates of epifaunal prey. Further research on the effects of structural complexity in marine systems and elsewhere should consider how factors that covary with habitat structure may add complexity to simple relationships between habitat structure and predation.

Acknowledgements. We thank B. Hembrough, L. Segui, K. Tait, E. Moore, K. Withy-Allen, K. Nichols, M. Castorani, M. Colvin, L. Lewis, K. McCoy, C. McCoy, S. Byron, C. Renck, L. Foley, and G. Lannin for assistance in the lab and with collection of organisms. Funding for this research was supported by the Port of San Diego and the San Diego State University Research Foundation. This is contribution no. 17 from the SDSU Coastal \& Marine Institute Laboratory.

\section{LITERATURE CITED}

- Anderson TW (2001) Predator responses, prey refuges, and density-dependent mortality of a marine fish. Ecology 82 : 245-257

Andren H (1994) Effects of habitat fragmentation on birds and mammals in landscapes with different proportions of suitable habitat: a review. Oikos 71:355-366

> Attrill MJ, Strong JA, Rowden AA (2000) Are microinvertebrate communities influenced by seagrass structural complexity? Ecography 23:114-121

> Bartholomew A, Diaz RJ, Cicchetti G (2000) New dimensionless indices of structural habitat complexity: predicted and actual effects on a predator's foraging success. Mar Ecol Prog Ser 206:45-58

Beck MW (2000) Separating the elements of habitat structure: independent effects of habitat complexity and structural components on rocky intertidal gastropods. J Exp Mar Biol Ecol 249:29-49

$>$ Bologna PAX, Heck KL Jr (1999) Differential predation and growth rates of bay scallops within a seagrass habitat. J Exp Mar Biol Ecol 239:299-314

> Canion CR, Heck KL Jr (2009) Effect of habitat complexity on predation success: re-evaluating the current paradigm in seagrass beds. Mar Ecol Prog Ser 393:37-46

Coen LD, Heck KL Jr, Abele LG (1981) Experiments on competition and predation among shrimps of seagrass meadows. Ecology 62:1484-1493

Cook WL, Streams FA (1984) Fish predation on Notonecta (Hemiptera): relationship between prey risk and habitat utilization. Oecologia 64:177-183

Corona A, Soto LA, Sanchez AJ (2000) Epibenthic amphipod abundance and predation efficiency of the pink shrimp Farfantepenaeus duorarum (Burkenroad, 1939) in habitats with different physical complexity in tropical estuarine system. J Exp Mar Biol Ecol 253:33-48

> Crowder LB, Cooper WE (1982) Habitat structural complexity and the interaction between bluegills and their prey. Ecology 63:1802-1813

Davis JLD, Metcalfe WJ, Hines AH (2003) Implications of a fluctuating fish predator guild on behavior, distribution, and abundance of a shared prey species: the grass shrimp Palaemonetes pugio. J Exp Mar Biol Ecol 293: $23-40$

Donovan TM, Jones PW, Annand EM, Thompson FR III (1997) Variation in local-scale edge effects: mechanisms and landscape context. Ecology 78:2064-2075

Flynn AJ, Ritz DA (1999) Effect of habitat complexity and predatory style on the capture success of fish feeding on aggregated prey. J Mar Biol Assoc UK 79:487-494

Gates JE, Gysel LW (1978) Avian nest dispersion and fledgling success in field-forest ecotones. Ecology 59:871-883

> Gorman OT, Karr JR (1978) Habitat structure and stream fish communities. Ecology 59:507-515

> Gotceitas V, Colgan P (1990) The effects of prey availability and predation risk on habitat selection by juvenile blue gill sunfish. Copeia 1990:409-417

Gotelli NJ, Ellison AM (2004) A primer of ecological statistics. Sinauer Associates, Sunderland, MA

> Graham S, Davis J, Deegan L, Cebrian J, Hughes J (1998) Effect of eelgrass (Zostera marina) density on the feeding efficiency of mummichog (Fundulus heteroclitus). Biol Bull 195:241-243

Griesser M, Nystrand M (2009) Vigilance and predation of a forest-living bird species depend on large-scale habitat structure. Behav Ecol 20:709-715

Heck KL Jr, Crowder LB (1991) Habitat structure and predator-prey interactions in vegetated aquatic systems. In: Bell SS, McCoy ED, Mushinsky HR (eds) Habitat structure: the physical arrangement of objects in space. Chapman \& Hall, London, p 281-299

Heck KL Jr, Thoman TA (1981) Experiments on predatorprey interactions in vegetated aquatic habitats. J Exp Mar Biol Ecol 53:125-134

> Heck KL Jr, Wetstone GS (1977) Habitat complexity and invertebrate species richness and abundance in tropical seagrass meadows. J Biogeogr 4:135-142

> Heck KL Jr, Able KW, Fahay MP, Roman CT (1989) Fishes and decapods crustaceans of Cape Cod eelgrass meadows: species composition, seasonal abundance patterns and comparison with unvegetated substrates. Estuaries 12:59-65

> Hovel KA, Fonseca MS (2005) Influence of seagrass landscape structure on the juvenile blue crab habitat-survival function. Mar Ecol Prog Ser 300:179-191

Hovel KA, Lipcius RN (2001) Habitat fragmentation in a seagrass landscape: patch size and complexity control blue crab survival. Ecology 82:1814-1829

Irlandi EA (1997) Seagrass patch size and survivorship of an infaunal bivalve. Oikos 78:511-518

James PL, Heck KL Jr (1994) The effects of habitat complexity and light intensity on ambush predation within a simulated seagrass habitat. J Exp Mar Biol Ecol 176:187-200

Kunkel KE, Pletscher DH (2000) Habitat factors affecting vulnerability of moose to predation by wolves in southeastern British Columbia. Can J Zool 78:150-157

Lipcius RN, Hines AH (1986) Variable functional responses 
of a marine predator in dissimilar homogenous microhabitats. Ecology 67:1361-1371

Main KL (1987) Predator avoidance in seagrass meadows: prey behavior, microhabitat selection, and cryptic coloration. Ecology 68:170-180

Manatunge J, Asaeda T, Priyadarshana T (2000) The influence of structural complexity on fish-zooplankton interactions: a study using artificial submerged macrophytes. Environ Biol Fishes 58:425-438

> Mattila J, Heck KL Jr, Millstein E, Miller E, Gustafsson C, Williams SL, Bryon D (2008) Increased habitat structure does not always provide increased refuge from predation. Mar Ecol Prog Ser 361:15-20

McCoy ED, Bell SS (1991) Habitat structure: the evolution and diversification of a complex topic. In: Bell SS, McCoy ED, Mushinsky HR (eds) Habitat structure: the physical arrangement of objects in space. Chapman \& Hall, London, $\mathrm{p}$ 3-27

Michel MJ, Adams MM (2009) Differential effects of structural complexity on predator foraging behavior. Behav Ecol 20:313-317

Moksnes PO, Lipcius RN, Pihl L, van Montfrans J (1997) Cannibal-prey dynamics in juveniles and postlarvae of the blue crab. J Exp Mar Biol Ecol 215:157-187

> Moore EC, Hovel KA (2010) Relative influence of habitat complexity and proximity to patch edges on seagrass epifaunal communities. Oikos 119:1299-1311

Mullin SJ, Gutzke WHN (1999) The foraging ecology of the gray rat snake (Elaphe obsolete spiloides). I. Influence of habitat structural complexity when searching for mammalian prey. Herpetologica 55:18-28

Orth RJ (1992) A perspective on plant-animal interactions in seagrasses: physical and biological determinants influencing plant and animal abundance. In: John DM, Hawkins SJ, Price JH (eds) Plant-animal interactions in the marine benthos. Clarendon Press, Oxford, p 147-164

> Orth RJ, van Montfrans J (2002) Habitat quality and prey size as determinants of survival in post-larval and early juvenile instars of the blue crab Callinectes sapidus. Mar Ecol Prog Ser 231:205-213

> Orth RJ, Heck KL Jr, van Montfrans J (1984) Faunal communities in seagrass beds: a review of the influence of plant structure and prey characteristics on predator-prey relationships. Estuaries 7:339-350

Orth RJ, Luckenbach ML, Marion SR, Moore KA, Wilcox DJ (2006) Seagrass recovery in the Delmarva coastal bays. Aquat Bot 84:26-36

Paton PW (1994) The effect of edge on avian nest success: how strong is the evidence? Conserv Biol 8:17-26

Petren K, Case TJ (1998) Habitat structure determines competition intensity and invasion success in gecko lizards. Proc Natl Acad Sci USA 95:11739-11744

Robinson SK, Thompson FR III, Donovan TM, Whitehead DR, Faaborg K (1995) Regional forest fragmentation and the nesting success of migratory birds. Science 267: 1987-1990

Ryer CH (1988) Pipefish foraging: effects of fish size, prey

Editorial responsibility: Ivan Nagelkerken,

Nijmegen, The Netherlands size, and altered habitat complexity. Mar Ecol Prog Ser 48:37-45

Ryer CH, Stoner AW, Titgen RH (2004) Behavioral mechanisms underlying the refuge value of benthic habitat structure for two flatfishes with differing anti-predator strategies. Mar Ecol Prog Ser 268:231-243

> Savino JF, Stein RA (1982) Predator-prey interaction between largemouth bass and bluegills as influenced by simulated, submersed vegetation. Trans Am Fish Soc 111:255-266

Savino JF, Stein RA (1989) Behavioral interactions between fish predators and their prey: effects of plant density. Anim Behav 37:311-321

Seitz RD, Lipcius RN, Hines AH, Eggleston DB (2001) Density-dependent predation, habitat variation, and the persistence of marine bivalve prey. Ecology 82:2435-2451

Selgrath JC, Hovel KA, Wahle RA (2007) Effects of habitat edges on American lobster abundance and survival. J Exp Mar Biol Ecol 353:253-264

Sponaugle S, Lawton P (1990) Portunid crab predation on juvenile hard clams: effect of substrate type and prey density. Mar Ecol Prog Ser 67:43-53

Stein RA, Magnuson JJ (1976) Behavioral response of crayfish to a fish predator. Ecology 57:751-761

Stoner AW (1980) Perception and choice of substratum by epifaunal amphipods associated with seagrass. Mar Ecol Prog Ser 3:105-111

Stoner AW (1982) The influence of benthic macrophytes on the foraging behavior of pinfish, Lagodon rhomboides (Linnaeus). J Exp Mar Biol Ecol 58:271-284

Stoner AW (2009) Predicting freeze-related discard mortality in Alaskan crabs using a reflex impairment index. Fish Bull 107:395-402

Summerson HC, Peterson CH (1984) Role of predation in organizing benthic communities of a temperate-zone seagrass bed. Mar Ecol Prog Ser 15:63-77

- Tarr TL, Babbitt KJ (2002) Effects of habitat complexity and predator identity on predation of Rana clamitans larvae. Amphib-reptil 23:13-20

Valentine J, Duffy JE (2006) The central role of grazing in seagrass ecology. In: Larkum AWD, Orth RJ, Duarte CM (eds) Seagrasses: biology, ecology and conservation. Springer, New York, NY, p 463-501

van Dolah RF (1978) Factors regulating the distribution and population dynamics of the amphipod Gammarus palustris in an intertidal salt marsh community. Ecol Monogr 48:191-217

> Werner EE, Gilliam JF, Hall DJ, Mittelbach GG (1983) An experimental test of the effects of predation risk on habitat use in fish. Ecology 64:1540-1548

Williams SL, Heck KL Jr (2001) Seagrass communities. In: Bertness MD, Gaines SD, Hay ME (eds) Marine community ecology. Sinauer Press, Sunderland, MA, p 317-337

Willson MF (1974) Avian community organization and habitat structure. Ecology 55:1017-1029

Zar JH (2009) Biostatistical analysis, 5th edn. Pearson, Upper Saddle River, NJ

Submitted: January 5, 2011; Accepted: September 9, 2011

Proofs received from author(s): November 23, 2011 